\title{
Invisible Refugees and/or Overlapping Refugeedom? Protecting Sahrawis and Palestinians Displaced by the 2011 Libyan Uprising
}

\section{ELENA FIDDIAN-QASMIYEH*}

\begin{abstract}
This article examines the experiences of two North African and Middle Eastern refugee populations (Sahrawis and Palestinians) affected by the 2011 conflict in Libya who have remained largely invisible to the international community. The challenges that they have faced since the outbreak of violence in February 2011, and the nature of international responses to these challenges, highlight a range of interconnected issues on both conceptual and practical dimensions. After outlining the scale and nature of the internal and international displacement arising from the 2011 conflict, and the history of these refugees' presence in Libya, the article explores whether Sahrawis and Palestinians can be categorised and conceptualised as 'refugees' in Libya, given their 'voluntary' migration to the country for educational and/or employment purposes. Drawing on a number of historical examples of protection activities by UNHCR for Sahrawi and Palestinian 'refugee-migrants', the article explores the potential applicability of a framework that highlights 'overlapping refugeedoms' without negating refugees' agency. Given that neither population has a 'country of origin' or effective diplomatic protection, the article then explores which state and nonstate actors could be considered to be responsible for their protection in this conflict situation. Finally, analysing the 'solutions' promoted for Sahrawi and Palestinian refugees in this context leads to an assessment of whether such responses can be considered to offer effective protection to these populations. Ultimately, the article examines a range of protection gaps that emerge from these groups' experiences during the 2011 North African uprisings, arguing in favour of a critical assessment of the protection mechanisms in place to support refugees who 'voluntarily' migrate for economic and educational purposes. Such an evaluation is particularly important given policy-makers' increasing interest in presenting mobility as a 'fourth durable solution'.
\end{abstract}

\section{Introduction}

This article examines the experiences of two Middle Eastern refugee populations affected by the 2011 conflict in Libya: Sahrawis and Palestinians.

* Departmental Lecturer in Forced Migration, Refugee Studies Centre, University of Oxford. An earlier version of this article was presented at the 'North Africa in Transition: Mobility, Forced Migration and Humanitarian Crises' workshop (Refugee Studies Centre, 6 May 2011), and an earlier draft of the article is available: New Issues in Refugee Research, Research Paper no 225 (UNHCR, Geneva, 2011). Thanks are due to the Editor, the anonymous reviewers, and the workshop participants who offered feedback on earlier versions of the article. 
Both refugee communities and their respective political representatives, the Polisario Front and Palestine Liberation Organisation (PLO), have received support from the Libyan government since the 1970s, including through the provision of scholarships to enable refugee children and youth to complete their studies in Libya. Whilst unexamined by academics to date, thousands of Sahrawi and Palestinian refugees have studied in Libya throughout this period, although both groups faced expulsions from the country when political relations between Gaddafi and the Polisario/PLO were fraught. At the outbreak of the conflict in Libya in February 2011, it is estimated that over 900 Sahrawi children and youth, 100 Palestinian students, and between 50,000 and 70,000 Palestinian migrant workers were based in Libya. Their presence in Libya, the challenges they have faced since February 2011, and the nature of international responses to these challenges, highlight a spectrum of both conceptual and practical dilemmas. First, given their 'voluntary' migration to Libya for educational and/or employment purposes, are Sahrawis and Palestinians to be categorised and conceptualised as 'refugees' in Libya? Secondly, given that neither population has a 'country of origin' or effective diplomatic protection, which state and non-state actors can be considered to be responsible for their protection in this conflict situation? Thirdly, do the 'solutions' promoted for Sahrawi and Palestinian refugees offer effective protection to these populations, and what protection gaps are revealed through these groups' experiences during the 2011 Arab Spring?

In order to address these matters, the article is structured as follows. After a brief overview of the methodology underpinning this research, the scale and nature of the displacement that has resulted from the conflict is introduced, highlighting the extent to which certain displaced populations have been hyper-visible, whilst others have effectively been rendered invisible to (and by) the international community. It then turns to the case-studies of two of these 'invisible' populations, outlining the history of their presence in, and earlier expulsions from, Libya, and the extent to which their 'voluntary' presence there challenges popular conceptualisations of 'refugeehood' and 'forced migration'. Despite conceptual challenges surrounding the simultaneity of 'forced' and 'voluntary' migration, the article subsequently explores a range of historical precedents in which international agencies, including the United Nations High Commission for Refugees (UNHCR) and the United Nations Relief and Works Agency (UNRWA), have offered protection to Sahrawi and Palestinian refugees who have engaged in 'voluntary' educational and/ or economic migration. Given international commitments to offer a 'continuity of protection' to refugees, the final section of the article asks whether Sahrawi and Palestinian refugees who have been internally and internationally displaced by the conflict in Libya have received adequate 
levels and forms of protection, examining the nature and implications of the 'solutions' that have been proposed to date, and one which has yet to be fully activated.

\subsection{Methodology}

Given the total absence of published literature documenting and exploring the Sahrawi-Libyan scholarship programme, the Sahrawi case-study presented in this article is informed by three primary datasets that contextualise its development. First, reference is made to interviews conducted as part of a broader ESRC-funded doctoral research project with Sahrawi youth and adults in three main locations: Syria, Cuba, and the Algerian-based Sahrawi refugee camps. Secondly, fifty household interviews conducted in the Sahrawi refugee camps are drawn upon, which were undertaken for the University of Oxford's research project 'Children and Adolescents in Sahrawi and Afghan Refugee Households: Living with the Effects of Prolonged Armed Conflict and Forced Migration' (managed by Prof Chatty, and known as 'SARC'). ${ }^{1}$ Thirdly, the article refers to individual interviews that the author and Gina Crivello completed with fifty 7-12 year-old Sahrawi children in Spain, also as part of the SARG project. These interviews are supplemented with an analysis of recent Spanish and Sahrawi accounts pertaining to the situation of Sahrawi children and adolescents in the 2011 conflict in Libya. ${ }^{2}$

The Palestinian case-study in turn draws upon published materials and testimonials to contextualise the presence and experiences of Palestinians in Libya from the 1970s onwards, in addition to telephone interviews, conducted in March-September 2011, with the relatives of seven Palestinians affected by the conflict in Libya, and with two Palestinian families who were based in Benghazi at the outbreak of the conflict. Telephone and electronic communication with UNHCR and International Committee of the Red Cross and Red Crescent (ICRC) staff working on the identification and protection of refugees affected by the conflict also provided invaluable insight into the challenges facing displaced populations and international agencies alike. An analysis of international agency (primarily UNHCR, ICRC and the Office for the Coordination of Humanitarian Affairs (OCHA)) and Palestinian media reports vis à vis the situation of Palestinians affected by the conflict in 2011 is also presented throughout.

1 D Chatty, 'Introduction' in D Chatty (ed), Deterritorialised Afghan and Sahrawi Youth: Refugees from the Margins of the Middle East (Berghahn Books, 2010), 1-34. Acknowledgments and thanks are due to Prof Chatty for granting access to the SARC dataset.

2 A more detailed overview of this case-study, analysing interview extracts, is presented in E FiddianQasmiyeh, 'Sahrawi-Libyan educational migration: reflections and expectations' (in progress, available from the author upon request). 


\subsection{Background: displacement and the 2011 Libyan conflict}

Following the North African popular uprisings (known as the Arab Spring) ${ }^{3}$ that started in Tunisia in December 2010, anti-government protests in Libya rapidly escalated in February 2011 into a major conflict characterised by widespread attacks between pro- and anti-Gaddafi forces, a NATO-coordinated bombardment of the country, and mass displacement on both international and internal levels. Between February 2011 and 9 May 2011, UNHCR estimated that over 750,000 people, including approximately 267,000 'third country nationals' (that is, nonLibyans), had crossed from Libya into neighbouring countries; of these, circa 365,000 had fled to Tunisia and 270,830 to Egypt. ${ }^{4}$ A week later, the International Organisation of Migration (IOM) reported that the number of 'migrants' fleeing the violence had increased to 803,087, including 271,215 third country nationals; from the outbreak of violence to 16 May 2011, over 136,000 non-Libyans had been 'assisted' by IOM and its partners to return to their countries of origin. With reference to the scale of internal displacement, in May 2011 the Libyan Committee for Humanitarian Aid and Relief estimated that there were '200,000 internally displaced Libyans in Eastern Libya, of which 58,000 live in spontaneous settlement sites'. ${ }^{5}$

As the violence continued over the course of the summer, by lateAugust/early-September UNHCR reported that over 990,000 people had crossed from Libya to Tunisia, and 468,000 had fled to Egypt via the Salloum border crossing. ${ }^{6}$ In addition to third country nationals evacuated by the IOM and other international actors, the individuals based in UNHCR's camps in Tunisia included 'over 1,700 refugees and 2,100 asylum-seekers' while 'some 1,300 persons of concern to UNHCR, who cannot return home, remain[ed] at the [Libyan-Egyptian] border'. ' Given their particular protection needs, approximately 2,500 refugees had 'been submitted for resettlement from Tunisia and Egypt to a total of 12 resettlement countries' by mid-September. ${ }^{8}$ However, despite the UNHCR's Global Resettlement Solidarity Initiative being launched in April 2011, 'only 397 persons' had been resettled from Tunisia and Egypt by midSeptember $2011 .^{9}$

${ }^{3} A l-r a b \bar{t}^{\prime} a l-' a r a b \bar{\imath}$ is the term used in Arabic.

${ }^{4}$ UNHCR, 'Update no 24: Humanitarian Situation in Libya and the Neighbouring Countries'

(10 May 2011); UNHCR, 'Southern Tunisia Dehiba/Remada', Update no 7 (14 May 2011).

${ }^{5}$ UNHCR, Update no 24, ibid.

${ }^{6}$ UNHCR EXCOM, 'Update on UNHCR's operations in the Middle East and North Africa (MENA) - 2011'.

${ }^{7}$ Interestingly, the estimation of IDPs in Libya remained the same between May 2011 and Sept 2011: 'over 200,000 internally displaced persons in Libya', UNHCR EXCOM, ibid.

${ }^{8}$ UNHCR EXCOM, ibid.

9 ibid. 
As reflected by this brief overview, the conflict in Libya has centralised the multiple forms of migration, mobility, immobility and displacement that characterise the contemporary Middle East and North Africa (MENA), revealing overlapping flows and categories of individuals and collectivities based in the country. These include migrant workers with work permits and those in an irregular status, with such migrants originating from across South-East, East and Central Asia, Sub-Saharan Africa and the MENA region. The diversity of legal statuses held by these migrant workers is manifested not only in whether they hold work permits or are irregular migrants, but also with reference to their legal claims as citizens or refugees: while UNHCR had registered 8,000 refugees and 3,000 asylum seekers in Libya before the conflict, ${ }^{10}$ thousands more have never registered as asylum seekers, and yet may have fled a diversity of contexts that would correspond to the legal definitions applicable in Libya and neighbouring countries (the 1969 Organisation of African Unity regional refugee definition and the 1951 Geneva Convention international definition of a refugee).

In line with the above, since the onset of the violence in February 2011, different state and non-state actors have focused on particular groups that have been internally and internationally displaced. The European media has variously recognised the vulnerability of Libyan and 'third country nationals' crossing the Libyan-Egyptian and Libyan-Tunisian borders, whilst drawing on hyperbolic rhetoric vis à vis the purported 'threat' of a mass influx of Libyans, Tunisians and Sub-Saharan African migrants to European shores (especially to the Italian island of Lampedusa). Governments from around the world embarked on evacuating their own citizens from the area, with greater or lesser interest, investment and success. International organisations and UN agencies, including the IOM and the UNHCR, addressed a variety of populations requiring international assistance and protection to reach either their country of origin (in the case of migrant workers) or a safe third country (in the case of refugees and asylum seekers unable to return to their countries of origin). While these groups of citizens, migrants and refugees have been centralised by these and other actors, this article argues that certain populations' existence has been overshadowed or even rendered invisible to and by much of the international community. The remainder of this article focuses on two of these 'invisible' groups: Sahrawi and Palestinian refugee-students, and Palestinian refugee-migrants. It starts by providing a general overview of the presence of these two groups in Libya from the 1970 s to 2011.

\footnotetext{
${ }^{10}$ UNHCR, 'Revision to the UNHCR Supplementary Budget: The Libya Situation 2011' (Donor Relations and Resource Mobilization Service, Mar 2011).
} 


\section{Invisible refugees: Sahrawi and Palestinian refugees in Libya}

\subsection{A history of Sahrawi refugees' presence in Libya}

Since the Sahrawi liberation movement, the Polisario Front, established the Sahrawi refugee camps in South-Western Algeria in 1975, thousands of Sahrawi refugee children aged as young as 6 have left their refugee camp homes to study in Libya on full scholarships provided by Colonel Gaddafi. This has been part of a broader transnational education programme which Polisario developed to overcome the limited educational infrastructure in the refugee camps with the support of 'friendly' nations including Libya, Cuba and Algeria. ${ }^{11}$ After Algeria, which provides the largest number of scholarships to Sahrawi refugees, Libya has, until recently, been the second largest educational host for this refugee population. ${ }^{12}$ Although no reliable statistics exist vis à vis this programme, the two large datasets underpinning this case-study reflect the proportion of refugees who have participated in this scheme. Of fifty camp-based households interviewed by the SARC team, five interviewees had relatives who had studied in Libya (primarily sisters and daughters), while ten women (aged between 33 and 41) and four men (aged between 29 and 37) had left the camps between the ages of 6 and 8 to study in Libya in the 1970s and 1980s. In turn, sixteen of the fifty children aged between 7 and 12 interviewed by Crivello and Fiddian-Qasmiyeh in Spain referred specifically to the Libyan education programme, with twelve girls and four boys outlining the experiences of relatives (ranging from parents and aunts to siblings) who had studied there. ${ }^{13}$

\footnotetext{
${ }^{11}$ E Fiddian-Qasmiyeh, The Ideal Refugees: Gender, Islam and the Sahrawi Politics of Survival (Syracuse University Press, 2013); E Fiddian-Qasmiyeh, 'When the Self becomes Other: Representations of gender, Islam and the politics of survival in the Sahrawi refugee camps' in D Chatty and B Findlay (eds), Dispossession and Displacement: Forced Migration in the Middle East and North Africa (OUP, 2010), 17196; E Fiddian-Qasmiyeh, 'Paradoxes of Refugees' Educational Migration: Promoting self-sufficiency or renewing dependency?' (2011) 47 Comparative Education 433-47; D Chatty, E Fiddian-Qasmiyeh and G Crivello, 'Identity With/out Territory: Sahrawi Refugee Youth in Transnational Space' in Chatty and Findlay (eds), above, 35-82.

${ }^{12}$ Chatty, Fiddian-Qasmiyeh and Crivello, ibid, 59. According to a female Polisario representative who studied in Cuba, in 2003 there were '2,000 students in Libya, 3,000 in Algeria, and 1,400 in Cuba': F Coggan, 'Saharawi leader tours New Zealand', The Militant, 23 June, 2003. While the precise figures may have been inflated, the proportion of students appears to be consistent with the information provided by interviewees and the author's broader research vis à vis the Cuban-Sahrawi education programme: E Fiddian-Qasmiyeh, 'Representing Sahrawi Refugees' "Educational Displacement" to Cuba: Self-sufficient agents or manipulated victims in conflict?' (2009) 22 JRS 323-50; FiddianQasmiyeh, When the Self, ibid.

${ }^{13}$ Fourteen young men, interviewed by the author in Syria, Cuba and the refugee camps, also referred to the different types and fluctuating nature of Libya's support, although, given their participation in the Cuban and Syrian education programmes, they had not themselves studied in Libya.
} 
It is worth noting that Sahrawi children have not been eligible for primary-level scholarships since 1983, a year which marked a hiatus in the diplomatic and solidarity ties of the Polisario and Libya, following Libya's rapprochement with Morocco in 1983, and the eventual signing of the Moroccan-Libyan treaty of Arab-African Unity in August 1984. ${ }^{14}$ Due to this political conflict, Sahrawi children were expelled from Libya in $1984,{ }^{15}$ and the scholarship programme, which was eventually reinitiated in the late-1980s (when Libya protested King Hassan's talks with the Israeli Prime Minister in July 1986), was designed solely for secondary and tertiary level students. Between the 1990s and early-2011, Libya offered scholarships to hundreds of (and at times over a thousand) Sahrawi youth a year. Throughout this period, the majority of students have typically been female, ${ }^{16}$ with teenage girls and young women in their early-20s reportedly accounting for the majority of over 900 Sahrawi refugees who were waiting to be evacuated from Libya at the end of February 2011. In contrast to the late-1970s and early-1980s, when Sahrawi boarding schools were located across the country, ${ }^{17}$ in 2011, two boarding schools remained in Tripoli and Benghazi; other young Sahrawis were studying in Universities across the country. ${ }^{18}$

As suggested above, the presence of Sahrawi refugee students in Libya in 2011 has been largely invisible within the English-language media. ${ }^{19}$ Only one reference has been made by international agencies, when the UNHCR noted, on 6 March 2011, that the UN refugee agency had been informed of (rather than responsible for) the successful evacuation of 743 Sahrawi refugee children and youth by the Algerian authorities (as the Sahrawi's host state). Indeed, it is notable that, although UNHCR records the number of Sahrawi refugee children and youth studying in Cuba, ${ }^{20}$ UNHCR Statistical Yearbooks and Statistical Overviews have never documented the number of Sahrawi refugees in Libya. ${ }^{21}$ This raises the question, explored in greater detail below, of whether UNHCR was in fact

\footnotetext{
${ }^{14}$ See Fiddian-Qasmiyeh, above n 2.

1535 year-old, male SARC interviewee.

${ }^{16}$ Interviews in Syria and Cuba; this is also in line with demographic data from SARC and Madrid Interviews. See also Fiddian-Qasmiyeh, above n 2.

${ }^{17}$ SARC interviews.

18 'Testimonios desde Libya', El País (23 Feb 2011); A Muñoz, "Las abandonaron a su suerte" Mas de 7.000 estudiantes saharauis viven las revueltas atrapados en los dos internados libios que tienen el RASD en Trípoliy Bengasi', El País (4 Mar 2011).

${ }^{19}$ Numerous reports, which are unsubstantiated to date and vehemently refuted by Polisario representatives, have claimed that Sahrawi mercenaries were contracted by Gaddafi in 2011: see C Coughlin, 'Libya: Col Gaddafi "has spent f2.1m on mercenaries"', The Telegraph (20 Apr 2011); SPS, "It is neither the tradition nor the national interest of the POLISARIO Front to get involved in the sad situation in Libya", says Sahrawi diplomat', Sahrawi Press Service (12 Mar 2011).

${ }^{20}$ Fiddian-Qasmiyeh, Representing Sahrawi Refugees, above n 12; Fiddian-Qasmiyeh, When the Self, above n 11 .

${ }^{21}$ UNHCR Statistical Yearbooks and Statistical Overviews, 1995-2009.
} 
aware of the presence, number, whereabouts and protection needs of these refugee children and youth.

In contrast to this general invisibility, the Spanish media, including Spain's national newspaper El Pais, has centralised the experiences of Sahrawis in Libya, drawing upon Sahrawi students' testimonials, alongside those of Libyan citizens and third country migrant-workers, to outline conditions in the country. ${ }^{22}$ For instance, the experiences of two Sahrawi young women, aged 17 and 19, who had studied in Libya since they were 12, were relayed to/by El País through two main news articles, ${ }^{23}$ specifying that:

All of the Libyan personnel in the centre [the Sahrawi boarding school in Benghazi] abandoned the institution when the conflict started between the security forces and the demonstrators. Not even the cooks remained. They left [the girls], without food, until the people on the street started to feed them out of charity. ${ }^{24}$

Such a focus demonstrates the extent to which different actors have prioritised the protection needs of different migrant and refugee populations, in this case in part due to former colonial ties (Spain occupied the Western Sahara from 1884 until its departure from the territory in 1976) and broader Sahrawi-Spanish solidarity networks revolving around refugee children. ${ }^{25}$

\subsection{Palestinian refugees in Libya}

Predating the Sahrawi-Libyan education programme, Libya offered multifaceted support to Palestinian refugees from the early-1970s, including opening a PLO office in Tripoli, and offering scholarships for the completion of their secondary and tertiary studies. At the start of the 2011 conflict, 104 Palestinian refugee-students were reportedly attending university and military academies in Libya through the scholarship programme. ${ }^{26}$ Although all these refugee-students had been evacuated from Libya by early March 2011, at least one Palestinian refugee-student (Khan Younis, from the Gaza strip, who had been studying engineering at Misrata University) is reported to have been killed in Libya during the violence. The particular vulnerability of this cohort of young refugees was highlighted by his sister:

\footnotetext{
22 'Testimonios desde Libya', above n 18.

${ }^{23}$ ibid; Muñoz, above n 18.

${ }^{24}$ Muñoz, above n 18, author's translation.

${ }^{25}$ See below and Fiddian-Qasmiyeh, The Ideal Refugees, above n 11; also Fiddian-Qasmiyeh, 'Histories of Displacement: Intersections between ethnicity, gender and class' (2011) 16 Journal of North African Studies 31-48.

${ }^{26}$ 'Last group of Palestinian students leave Libya', Ma'an Neres Agency (7 Mar 2011).
} 
there is a dangerous level of incitement against the Palestinians in Libya ... the mercenaries of the Qaddafi regime are responsible for several attacks against the Palestinians in the country. ${ }^{27}$

Other news reports asserted that Gaddafi's forces had 'detained Palestinians studying at a military college in the northwestern city [of Misrata] after they refused to join the pro-regime forces' ${ }^{28}$

Unlike the Sahrawi refugee-students, who all originated from the same location (the Algerian-based refugee camps), Palestinian refugee-students had been habitually resident in a wide variety of countries/territories before travelling to Libya to take up their scholarships: including Gaza and the West Bank, Egypt, and the main Palestinian host countries in the region (Lebanon, Jordan and Syria). As discussed in detail below, such a diversity of points of 'origin' across the MENA region raise a number of difficulties when attempting to secure effective protection for Palestinians facing secondary displacement from Libya.

While Palestinians make up a much smaller number of refugee-students than their Sahrawi counterparts, thousands of Palestinian 'refugeemigrant-workers' have lived in Libya since the 1970s and continue to do so. Accounts documenting the labour migration of Palestinian workers to Libya draw on Palestinian and Libyan statistics to estimate that approximately 5,000 Palestinians were present in Libya in 1970, ${ }^{29} 23,759$ in $1981,{ }^{30}$ and 29,207 by the end of $1992 .{ }^{31}$ With reference to the gender of those present in the 1980s, Tahir draws on Palestinian statistics to estimate that in 1980/1981 there were approximately 14,600 Palestinian males and 9,100 Palestinian females present in Libya. ${ }^{32}$ Following the mass expulsion of Palestinians from Libya in 1995-1996 (see below), the number of Palestinians decreased dramatically to approximately 17,000 in $1996,{ }^{33}$ increasing over the course of the following decade to an estimated total of between 50,000 and 70,000 by the beginning of 2011 . While these figures are contested, it is clear that thousands of Palestinians have lived in Libya

${ }^{27}$ Cited in IMEMC, 'Palestinian Student Killed by Mercenaries in Libya', International Middle East Media Centre (26 Feb 2011).

28 'Gadhafi forces detain Palestinian students', Ma'an Newes Agency (2 Mar 2011).

${ }^{29}$ I Abu-Lughod, 'Educating a Community in Exile: The Palestinian Experience' (1973) 2 Journal of Palestine Studies 94-111.

${ }^{30}$ PA Smith, 'The Palestinian Diaspora, 1948-1985' (1986) 15 Journal of Palestine Studies 90-108, 90.

${ }^{31}$ Palestine Red Crescent Society, The Situation of the Palestine Refugees in Diaspora: Demographic, SocioEconomic Characteristics and Health Status (PRCS, 1994), 5.

${ }^{32} \mathrm{~J}$ Tahir, 'An Assessment of Palestinian Human Resources: Higher Education and Manpower' (1985) 14 Journal of Palestine Studies 32-53, 42.

33 'The Palestinian Crisis in Libya 1994-1996: Interview with Professor Bassem Sirhan' (2010) 45 al-Majdal, Forced Secondary Displacement: Palestinian Refugees in the Gaza Strip, Iraq, Jordan, and Libya. 
(either with work permits or in an irregular status) since the 1980s and 1990s. ${ }^{34}$

It is notable that, despite the long-standing presence of such significant numbers of Palestinian refugees in Libya, the experiences of Libya-based Palestinians, and of Palestinians expelled from Libya at different points between the 1970s and the present, have remained largely unexplored. ${ }^{35}$ More precisely, none of the existing academic and NGO references pertaining to Libya-based Palestinians refer to the scholarship programme, and only a small number focus on, or refer in passing to, Palestinian migrant-workers. While these 'categories' of Palestinians have been understudied, arguably the most 'invisible' status held by Palestinians in Libya is that of 'asylum seeker' or 'refugee', with an absence of academic or policy literature engaging with the existence of Palestinians as refugees in the country. Indeed, the cases referred to in this article as Sahrawi and Palestinian 'refugee-students' and Palestinian 'refugee-migrant-workers', raise a number of pivotal conceptual questions, including the continued applicability of the term 'refugee' in contexts of voluntary economic or educational migration.

\section{Migrants, 'internally displaced refugees' or 'second time refugees'?}

Throughout the conflict in 2011, Palestinian and Sahrawi refugee-students and Palestinian refugee-migrant-workers have variously become 'internally stuck refugees' and 'internally displaced refugees' unable to leave Libya, while hundreds if not thousands have also experienced secondary international displacement from Libya to Egypt or Tunisia. ${ }^{36}$ Two key intersecting questions arise in this respect: first, how to conceptualise Libya's role as a 'host' country for these groups before the conflict; and, secondly, how to

34 OCHA, 'Libyan Arab Jamahiriya - Crisis Situation Report No 27' (19 Apr 2011); telephone interview with Palestinian woman based in Benghazi, 8 Apr 2011. Witness testimonies refer to attacks on Palestinian households in Benghazi; further research is required to contextualise the experiences of Palestinian students and migrant workers during different phases of the conflict.

${ }_{35}$ Sirhan's personal testimony of having lived in Libya for three years in the early- to mid-1990s is drawn upon by both al-Majdal, above n 33, and BT Sirhan and A Khaleq, 'The Palestinians in Libya, Testimonies: The Crisis of the Palestinian Community in Libya: Two Years of Suffering' (1996/1997) IX The Palestine Yearbook of International Law 363-74; Libya-based Palestinians are mentioned passim by A Shiblak, 'Residency Status and Civil Rights of Palestinian Refugees in Arab Countries' (1996) 25 Journal of Palestine Studies 36-45; AF Kassim, 'The Palestinians: From Hyphenated to Integrated Citizenship' in NA Butenschon, U Davis and M Hassassian (eds), Citizenship and the State in the Middle East: Approaches and Applications (Syracuse University Press, 2000), 201-24; SM Akram, 'Palestinian refugees and their legal status: Rights, politics, and implications for a just solution' (2002) XXXI Journal of Palestine Studies 36-51; B Goddard, 'UNHCR and the International Protection of Palestinian Refugees' (2009) 28 RSQ475-510.

36 In the case of Palestinian refugees, this may in fact have accounted for perhaps even tertiary, quaternary, quinary, or senary displacement (see below). 
define and classify the status of Sahrawis and Palestinians whilst in, and when attempting to leave, this country during the Arab Spring.

According to Sirhan, a Palestinian sociologist who lived in Libya for three years before Gaddafi expelled thousands of Palestinians in 1995 (see below):

Libya is not a host country for Palestinians (i.e. Palestinians are not refugees there), as is the case with Lebanon, Syria and Jordan; it is rather one which imports skilled labour ... therefore the residency of any Palestinian in Libya is based on a personal or individual contract with the state and its institutions, or with Libyan companies or foreign companies operating in Libya. ${ }^{37}$

In this statement, Sirhan unequivocally asserts that Libya is not a 'host country' in the sense of being an 'asylum state' for Palestinians, 'as is the case' in other MENA countries that fall under UNRWA's areas of operation. This leads us to ask how we might define this hosting location: if it is not a 'host country' could it be conceptualised as a 'state of employment' or a 'state of education', or perhaps even as a 'transit state' inhabited between periods in asylum states in the region? In the context of Sahrawi children and youth who had been based in Libya for up to a decade, the denomination of Libya as an 'educational hosting context' may be accurate given the terms of their presence in the country. Such definitions, however, are particularly complicated in the case of Palestinian workers who have lived in Libya for over twenty years, since Libya was arguably their 'place of habitual residence' at the outbreak of the conflict.

Nonetheless, Sirhan not only argues that Libya is 'not a host country for Palestinians', but explicitly claims that 'Palestinians are not refugees there'. On the one hand, such a claim may be understandable in so far as Libya has considered Palestinians to be 'Arab citizens residing in Libya' rather than 'refugees', in line with its Reservation to article 1 of the Protocol for the Treatment of Palestinians in Arab States. Indeed, the vast majority of Palestinians in Libya had neither applied for asylum in Libya nor been admitted to Libya due to their refugee status per se; as such, Palestinians' status in the eyes of the Libyan government was not that of 'refugees', but rather that of 'skilled labourers'. Whilst unrecognised by Sirhan, it is important to note that broader debates persist vis à vis the effective status of Palestinians within the region, including in Jordan, Syria and Lebanon; although Sirhan asserts that Palestinians are refugees in these countries, these and other states (including Egypt) typically refuse to consider Palestinians to be refugees. This struggle is noted by Kagan, who recognises that Palestinian refugees 'are increasingly asking to be recognized as just refugees, full stop', thereby highlighting the disconnect that may exist between official UNHCR and UNRWA declarations vis à vis Palestinians'

\footnotetext{
37 Sirhan, quoted in al-Majdal, above n 33, 44 (emphasis added).
} 
status as refugees within and outside of UNRWA's areas of operations in the MENA region, and a variety of state and non-state practices that fail to offer them meaningful recognition and protection as refugees per se. ${ }^{38}$

On the other hand, the de-classification of Palestinians as 'refugees' and their re-classification as 'skilled labourers' simultaneously risks embracing a monolithic interpretation of identity and legal status that elides the multiple vulnerabilities and protection concerns held by different groups of people in diverse geopolitical contexts. In effect, the de-classification of Palestinians as refugees in this way appears to substantiate the interpretation that refugees who utilise their agency to find employment, or who voluntarily migrate to a third country to pursue their education, automatically risk losing the legitimate claim to 'refugee' status. This equation has many dangers, including the potential negation of refugees' capacity to be perceived to be active agents as refugees, and more specific practical implications such as potentially losing a variety of rights and types of international protection that (should) accompany refugee status.

This case-study therefore prompts the broader question of whether refugees who 'voluntarily' migrate for economic and educational purposes are conceptualised by different actors as being 'worthy' of international protection. Indeed, as researchers and policy-makers increasingly focus on the blurred nature of categories such as 'forced' and 'voluntary' migration, and explore the dynamics of the asylum-migration nexus, ${ }^{39}$ these refugees embody the overlaps of being legally recognised as refugees under international definitions, and simultaneously being educational/economic migrants who have decided to travel outside of their country of habitual residence or first country of asylum. The Palestinian and Sahrawi children,

38 M Kagan, 'The (Relative) Decline of Palestinian Exceptionalism and its Consequences for Refugee Studies in the Middle East' (2009) 22 JRS 417-38, 434. The disconnect referred to appears to emerge between the lived experiences of many Palestinians, who struggle to be recognised and to be offered meaningful protection as refugees across the region, and the official position that, 'Palestinians remain refugees whether they come here [to Libya] for economic reasons or not': Emmanuel Gignac, cited in "The Middle East's "Invisible Refugees"' IRIN (31 Jan 2011). The official position of a continuity of protection is consistent with mainstream interpretations of art 1D, in which "the phrase "[w] hen such protection or assistance has ceased for any reason" should be interpreted to include situations when Palestinian refugees have voluntarily left the UNRWA areas' (emphasis added): Goddard, above n 35, 496. However, the tension between theory and practice has nonetheless been recognised by UNHCR with reference to the position of Palestinians in Libya: 'Technically, there is no protection gap ... If you're a Palestinian in Libya, you do fall under UNHCR. It shouldn't be an issue mandate-wise or legalwise. But in practice, Palestinians being so political and all these sensitivities being around them, if we apply our mandate which includes [certain] solutions [ie, resettlement], there are issues': Gignac, cited in IRIN, above (emphasis added).

39 For instance, K Long, 'Home alone? A review of the relationship between repatriation, mobility and durable solutions for refugees', UNHCR Evaluation Paper (2010); K Long, 'Extending Protection? Labour migration and durable solutions for refugees', New Issues in Refugee Research Working Paper Series, no 176 (UNHCR 2009); and N Van Hear, R Brubaker and T Bessa, 'Managing mobility for human development: the growing salience of mixed migration', Human Development Research Paper Series, no 19202 (2009). 
adolescents and adults referred to in this article thereby reflect the potential simultaneity of being a 'voluntary' and an 'involuntary migrant', and of the specific protection needs of those referred to in this article as 'refugee-migrant-workers' and 'refugee-students'. Recognising the specificities of these protection concerns is particularly important in light of increasing policy support for migration and mobility as a 'fourth durable solution'; 40 'voluntary migration' may lead to increased risk, rather than being an effective and durable solution per se.

In fact, this article argues that there are multiple reasons for purposefully highlighting the refugee status of Palestinians and Sahrawis in Libya, leading not only to the recognition of the potential simultaneity of being both 'forced' and 'voluntary' migrants, but also the potential benefits of a new conceptual categorisation of 'overlapping-refugeeness'.

First, from 1996 onwards, UNHCR's statistical unit has documented the total number of Palestinian refugees registered by the agency in Libya, indicating the number of new asylum applications made, and the total number of Palestinians receiving assistance from the organisation. One key reason underpinning the increased presence of UNHCR registered Palestinians from 1996 to the present is discussed below.

As evidenced in Table 1, UNHCR has recognised the presence and both the protection and assistance needs of thousands of Palestinian refugees in Libya, noting that of the 943 Palestinian applications for asylum in Libya in 2008, 544 were offered 1951 Geneva Convention Refugee Status, and 344 were granted complementary protection (sixty-three cases were pending at the end of the year). ${ }^{41}$

It is worth noting the discrepancies between the figures presented in various UNHCR reports, as reflected both in the divergent total populations documented in Tables 1 and 2, and in the apparent inconsistency between the presence of over 8,000 Palestinian refugees registered with UNHCR throughout the 2000s (with the number increasing each year between 2000 and 2004/5), and UNHCR's assertion that in 2011 a total of approximately 8,000 refugees and 3,000 asylum seekers of all nationalities were registered with the agency. An important question is therefore raised regarding the (in)visibility of thousands of Palestinians as refugees based in Libya within statistics pertaining to the contemporary conflict, with subsequent implications apropos protection.

UNHCR data also provide a pertinent insight into the demographic composition of Palestinian refugees of concern to the agency through its records of new asylum applications in the country at the end of 1996, 1998 and 2000 (Table 2 and Chart 1).

Long, Home alone, ibid.

${ }^{41}$ UNHCR Statistical Yearbook 2008, 117. 
276

Elena Fiddian-Qasmiyeh

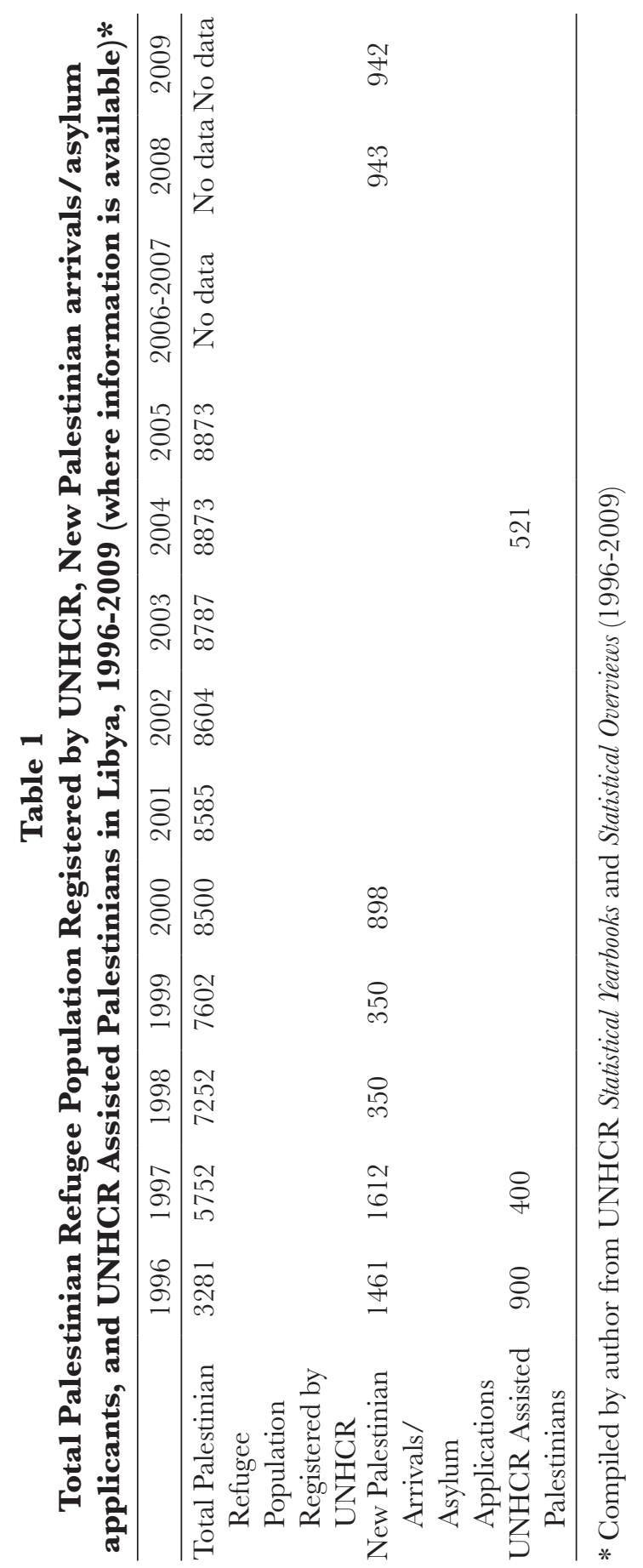




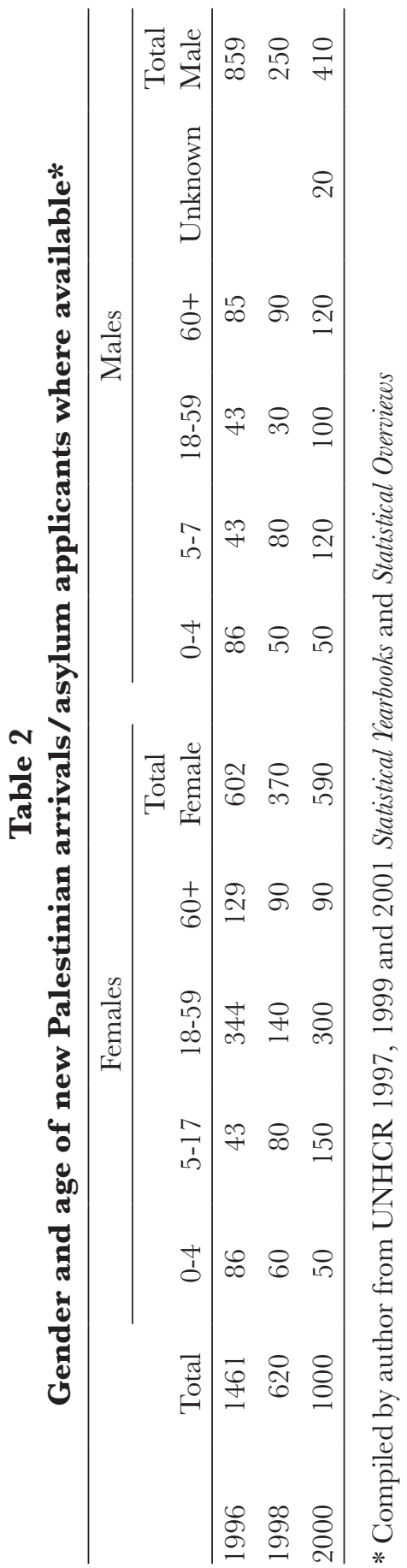




\section{Chart 1}

\section{Gender and age of new Palestinian asylum applicants in Libya in 1996, 1998 and 2000*}

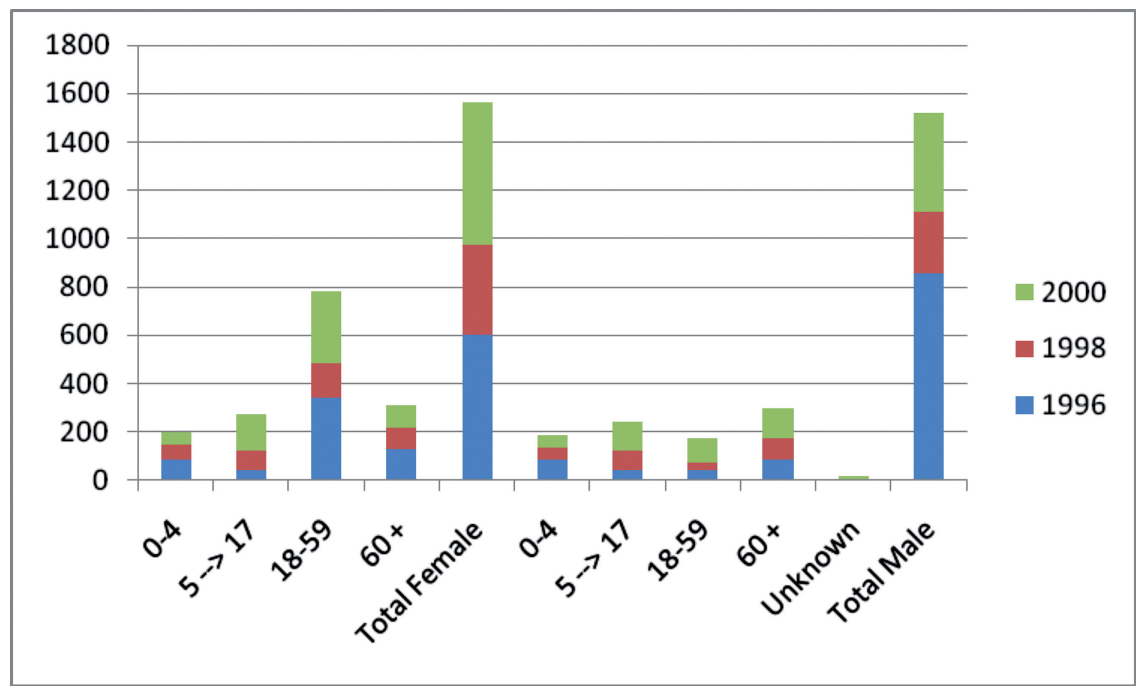

* Compiled by author from UNHCR 1997, 1999 and 2001 Statistical Yearbooks and Statistical Overviews

This demographic overview highlights the large number of Palestinian refugee children present in Libya between 1996 and 2000, suggesting that hundreds if not thousands of Palestinian children and youth will have remained in Libya throughout the following decade. Interestingly, the high proportion of Palestinian girls closely mirrors the gender and age of Sahrawi refugee-students based in Libya during the same period. The demographic composition of these populations must also be centralised in an ongoing assessment of the protection needs of these individuals, families and groups.

A second reason for highlighting, rather than potentially erasing, these refugees' refugee status per se arises when we recognise that thousands of Palestinians who were born as refugees and registered by UNRWA as refugees at birth in Gaza, West Bank, Lebanon, Syria, Jordan or Egypt, in this instance embody 'overlapping refugeedoms', having applied for and having been granted asylum in Libya (as per Table 1). For instance, in 1998 UNHCR-Libya received new asylum applications from 350 Palestinians from the Gaza Strip. ${ }^{42}$ Just as the UN High Commissioner for Refugees, Antònio Gutteres, argues that Somali, Eritrean and Ivorian asylum seekers

42 UNHCR Statistical Yearbook 2000. 
formerly based in Libya who have sought safety in Europe 'were refugees twice', ${ }^{43}$ so too can Palestinian refugees who attempted to seek sanctuary from the conflict in Libya be categorised as 'double refugees' (a phrase used by Sachs) ${ }^{44}$ or as 'second time refugees' (a term coined by Shiblak), ${ }^{45}$ to denote the multiple experiences of displacement characterising certain refugee populations. ${ }^{46}$ While the expulsion of Palestinians from Libya in 1995 has been denominated as 'secondary displacement', in the case of Palestinian refugees displaced in 2011, this may in fact have accounted for tertiary, quaternary, quinary, or even senary displacement. Equally, it can therefore be argued that they may experience secondary, tertiary or quaternary 'refugeehood', with overlapping vulnerabilities across time and space, and accentuated, rather than erased, protection needs.

Although the overlapping refugeehood of Palestinians explicitly registered as refugees by UNHCR may be particularly clear in this respect, it can equally be maintained that such refugee status determination processes do not make someone a refugee but, rather, offer an official declaration that confirms a legal status/identity in the eyes of states and international organisations. ${ }^{47}$ As such, Palestinians present in Libya may 'be' 1951 Geneva Convention refugees even if they have not applied for asylum, by virtue of inherently fulfilling all of the legal criteria that would (or should, in the absence of procedural errors and the misapplication of law) lead to an official declaration of their de jure refugee identity.

A third reason for arguing that Sahrawi and Palestinians' refugeehood should be centralised in spite of the 'voluntary' nature of their economic and/or educational migration to Libya, leading to the implementation of proactive protection mechanisms, derives from examples of the ways in which the UN has addressed the protection needs of both of these groups in the past.

\section{Precedents of protection (and histories repeating themselves)}

Two key examples centralise the continuity of 'refugeehood' and the need for international protection in contexts of so-called voluntary migration.

\footnotetext{
43 This statement was made in relation to the tragic drowning of these individuals: they were 'refugees twice' as 'they fled war and persecution in their own counties and now, in their attempt to seek safety in Italy, they tragically lost their lives': 'UNHCR High Commissioner for Refugees and UNHCR Goodwill Ambassador shocked by devastating boat tragedy', UNHCR Press Release (6 Apr 2011).

44 A Sachs, 'Apartheid, Destabilization and Refugees' (1989) 2 JRS 491-501.

45 Shiblak invokes this concept to refer to Palestinians from Gaza who were displaced both in 1948 and 1967. Shiblak, above n 35, 40.

46 See also E Fiddian-Qasmiyeh and YM Qasmiyeh, 'Asylum-Seekers and Refugees from the Middle East and North Africa: Negotiating politics, religion and identity in the UK' (2010) 23 JRS 294-314.

${ }^{47}$ E Fiddian-Qasmiyeh, 'Relocating: The Asylum Experience in Cairo' (2006) 8 Interventions: International Journal of Postcolonial Studies 295-318.
} 


\subsection{UNHCR and the protection of Sahrawi educational migrants in Guba}

The first example pertains to the UN's active involvement in monitoring the protection situation of Sahrawi youth who have engaged in voluntary educational migration to Cuba, and yet have continued to be considered refugees in need of protection by UNHCR whilst studying in the Caribbean. ${ }^{48}$ Throughout the 1970s and 1980s, the Cuban government was entirely responsible for these children; however, since Cuba has full diplomatic relations with the Sahrawi Arab Democratic Republic (the Sahrawi state-in-exile whose birth was declared by the Polisario Front in 1976), Cuba considers Sahrawi students to be citizens of this 'state', rather than refugees per se during their stay on the island. ${ }^{49}$ However, since 1994, the Cuban government (facing major difficulties as a result of the US-led Embargo and the fall of the Soviet bloc) explicitly requested that UNHCR become involved in overseeing the arrival and presence of Sahrawi children on the island. Since then, whilst explicitly noting that Sahrawi children are present voluntarily on the island, UNHGR has supervised the protection situation of Sahrawi children in Cuba, providing a small stipend to all students, in addition to regularly monitoring their situation and publishing Information Notes confirming that they are being treated in accordance to international standards of treatment and care, as required by the 1989 Convention on the Rights of the Child. ${ }^{50}$

\subsection{Palestinian 'secondary displacement' from Libya}

The second example is the most pertinent in light of the recent conflict, and provides the main reason for the dramatic increase in the number of Palestinians applying for asylum after 1996.

As a means of protesting the Palestine Liberation Organisation's signing of the Oslo Accords, in September 1995 Gaddafi threatened to expel all the estimated 30,000 Palestinian 'migrant workers' based in Libya at the time. ${ }^{51}$ It is estimated that 13,000 Palestinians were deported over the course of the following eight months, with 17,000 reportedly remaining in the country by May 1996..$^{52}$ In September 1995, the Salloum border saw the establishment of Mukhayyam Al-Awda (the Return Camp) by Gaddafi's forces. Despite the

\footnotetext{
48 Interview, UNHCR official, Habana, Nov 2006.

49 See Fiddian-Qasmiyeh, The Ideal Refugees, above n 11.

50 Fiddian-Qasmiyeh, 'Representing Sahrawi Refugees', above n 12; UNHCR, 'Summary Update of Machel Study: Follow-up activities in 2001-2002' (Refugee Children Coordination Unit, 2003); UNHCR, 'Information Note: Western Saharan refugee students in Cuba' (Sept 2005); also FiddianQasmiyeh, 'Education, Migration and Internationalism: Situating Muslim Middle Eastern and North African students in Cuba' (2009) 15 The Journal of North African Studies 137-55.

${ }^{51}$ '[A]s per a census conducted by the Libyan Foreign Security Agency in 1995 ... the number of Palestinians in Libya stood at 30,000': Sirhan, in al-Majdal, above n 33, 45.

52 al-Majdal, ibid, 47.
} 
name of the camp reflecting Gaddafi's invocation of the Palestinians' Right to Return (as enshrined in UN Resolutions 194 and 3236), in September 1995, 32 Palestinians were stranded in the 'Egyptian-Libyan no-man's land', by October 1995 approximately 900 Palestinians were stuck at the border, and over 200 remained by January 2006, unable to leave Libya and enter Egyptian territory. ${ }^{53}$ Unlike the 2011 conflict, which saw thousands of Palestinians proactively attempting to leave Libya in order to escape the violence, in 1995-1996 a large proportion of Palestinian 'migrant workers' were forcibly collected, transported and deported by Gaddafi's forces; by the end of September 1995 alone, 1,500 Palestinians had been transported to the Tubrok Camp in the north-east of Libya, in preparation for deportation by land (via the Salloum border) or sea. ${ }^{54}$

Indeed, over 600 Palestinians with Syrian and Jordanian identity documents were expelled by sea and were eventually collected by a Syrian ship (having initially been refused permission to land in Cyprus), leading to 608 Palestinians returning to Syria and thirteen to Jordan. ${ }^{55}$ However, in addition to major challenges in crossing into Egypt, even when holding Egyptian travel documents ${ }^{56}$ and restrictions on entering Gaza (with thirty-six Palestinians stuck at the Rafah crossing in September 1995 alone), ${ }^{57}$ most countries in the region under UNRWA's area of operations introduced further 'restrictions on the entry of Palestinians, even on those who had right of residence'. ${ }^{58}$ The Lebanese authorities, for instance, issued Decree No 478, which entered into effect on 10 September 1995, requiring that all Palestinians who had been refugees in Lebanon from 1948 obtain an exit visa from Lebanon and an entry visa from Lebanese diplomatic missions. ${ }^{59}$ Both of these bureaucratic procedures were evidently impossible for Palestinians forcibly taken to the border, and, as noted by Kassim, 'these measures are, in effect, a nullification of [these Palestinians'] residence and travel rights' ${ }^{60}$ Facing such hostile environments on both sides of the Libyan border, in 1995/1996 thousands of Palestinians recognised that they were simultaneously 'internally stuck', unable and unwilling to attempt to access other UNRWA states, and in need of international protection. Noting their effective statelessness ${ }^{61}$ and their inability to return to a safe 'country of origin' or alternative 'location

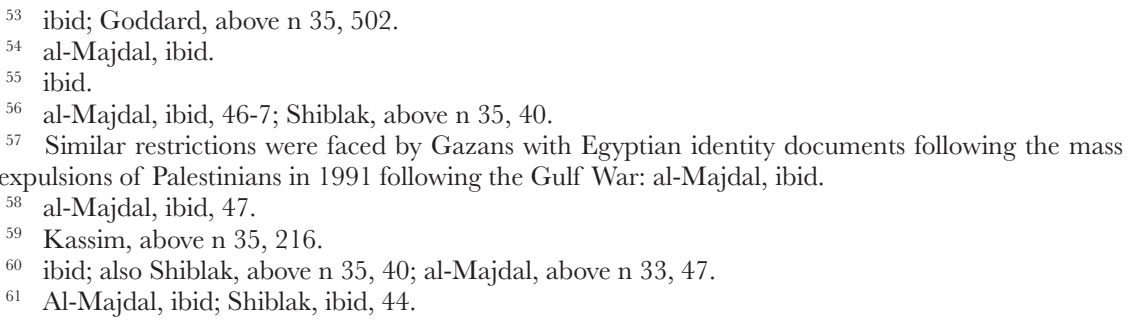


of habitual residence' in the region, thousands of Palestinians applied for asylum within Libya.

Throughout this period, 'UNHCR provided assistance to those at the [Egyptian-Libyan] border and monitored their situation until they were allowed to return to Libya in 1997'.62 On 29 September 1995, UNHCR and UNRWA issued a joint statement on the 'Forced Movement of Palestinians from Libya', ${ }^{63}$ being the first time that the two UN refugee agencies had 'issued a joint press release on a matter of mutual concern'. ${ }^{64}$ In addition to lobbying neighbouring countries to allow Palestinians holding valid documentation to enter their former-host states, as noted above, UNHCR witnessed an increased number of applications for asylum from Palestinians in Libya who had a well founded fear of attempting to relocate within the region. UNRWA's involvement in working with UNHCR to maximise the granting of effective protection to Palestinians in 1995-1996 raises questions regarding the organisation's absence in 2011.

Following the 1995-1996 mass expulsions, an unknown number of Palestinians eventually returned to Libya in search of work, but found themselves in a highly tentative and uncertain situation; thousands reportedly stayed in an irregular status, fearful of renewing their work permits and engaging with the Libyan authorities. ${ }^{65}$ Such fears are grounded in an acute awareness of the vulnerability of Palestinians in the country, as the 1995-1996 episode was neither the first nor only instance of Palestinian expulsion from Libya: hundreds of Palestinian migrant-workers were expelled in March 1971, ${ }^{66}$ while more recently, in March 2007, Gaddafi had once again threatened to deport all Palestinians to Gaza 'in retaliation for the latest Arab peace initiative' ${ }^{97}$

This example therefore illustrates the extent to which UNHCR has an established history of engaging in protection activities for populations with overlapping statuses as 'voluntary' and 'involuntary' migrants, in addition to highlighting the ongoing vulnerability experienced by Palestinian refugees in the region.

\section{Continuity of Protection: what, where and who?}

Following the outbreak of conflict in Libya in 2011, a number of 'solutions' were sought and implemented by the international community for these

\footnotetext{
62 Goddard, above n 35, 501-2.

63 Cited in al-Majdal, above n 33, 47.

64 Goddard, above n 35, 504.

65 Telephone interview, Benghazi resident, Apr 2011; telephone interview, Benghazi resident, Sept 2011; personal communication, relative of Palestinian refugee in Tripoli, Apr 2011. Further research is required to substantiate these claims.

66 WA Otman and E Karlberg, The Libyan Economy: Economic Diversification and International Repositioning (Springer, 2007), 36.

67 R Nahmias, 'Libya threatens to deport Palestinian refugees to Gaza', $1 \mathcal{N e t}$ (17 Mar 2007).
} 
'invisible' refugee populations formerly based in Libya. When examining the situation, two main related questions arise: what can be considered to be 'effective protection', and who can be considered to hold a responsibility to protect these populations: the refugees' political representatives (the Polisario Front and PLO/Palestinian Authorities respectively), UNHCR, UNRWA (in the case of Palestinians), the international community, or former and current host countries?

\subsection{Protecting Sahrawi refugees}

In the context of the relatively small total number of Sahrawi refugees (approximately 900), and the existence of one, active asylum host state (Algeria), evacuating Sahrawis from Libya has appeared to be more feasible than offering protection to up to 70,000 Palestinians previously based across the region. In this instance, on 7 March 2011, the Sahrawi Press Service (SPS) reported the return of 'some 916 Sahrawi students who pursued their secondary and university education and vocational training in Libya' to the Sahrawi refugee camps on 5 March. ${ }^{68}$ SPS was informed by the Sahrawi Minister of Education, Mariem Salek Hmada, that:

All the Sahrawi students in Libya, including girls, arrived safe and healthy in the Sahrawi refugee camps ... The students have been repatriated under good conditions and without incident. ${ }^{69}$

The evacuation of Sahrawi children from Libya by the Sahrawi's host state, Algeria, and their 'repatriation' to the refugee camps leads us to ask: to what extent can protection needs be considered to be upheld when refugee children who have experienced secondary displacement by armed conflict are returned to a desert-based refugee camp? Indeed, can return to a refugee camp be considered to be a 'solution' in such a context? Furthermore, given that 'repatriation' refers to the return of an individual or group to her/his country of origin (the Latin prefix re- indicating a movement 'back' and patria meaning 'native land'), is it appropriate to use such a term in this context? If 'repatriation' is not considered to be appropriate or accurate (since the refugee camps are not these children's 'country of origin'), what alternative conceptualisations exist to capture such complex dynamics? These issues require further investigation, drawing on both Sahrawi refugees' and UNHCR's perceptions of 'safety', 'effective protection' and 'solutions'.

Another set of questions pertains to the responsibility of diverse actors to offer these children international protection. As indicated above, the Sahrawi students were ultimately evacuated by the Algerian authorities,

68 S El-Hafed, 'Return to Sahrawi refugee camps of Sahrawi students in Libya', Sahrawi Press Service (7 Mar 2011).

69 El-Hafed, ibid (emphasis added). 
who reportedly liaised with Polisario to enable the children's return to their host state. However, it is notable that Spanish civil society also played a highly active role in lobbying Polisario to push for the children's evacuation: Spanish families host up to 10,000 Sahrawi children a year as part of the Holidays in Peace programme ${ }^{70}$ and many of these children have subsequently travelled to Libya to complete their secondary and tertiary studies. In 2011, Spanish civil society also established numerous campaigns to mobilise public and political support ${ }^{71}$ for the evacuation of these children and adolescents, including blogs such as <http://www.saharaponent. net/2011/02/estudiantes-saharauis-en-libia.html>, which actively traced the whereabouts of Sahrawi refugee children in Libya, disseminating information to interested Spanish individuals and families, and sharing opinions regarding Polisario's management of the crisis. Such initiatives were recognised by Polisario in a number of ways. For instance, shortly after the outbreak of violence, the Polisario representative to Madrid is reported to have stated that: "the Sahrawi adolescents who are studying in Libya are "safe", reiterating that 'the Sahrawi authorities have not considered an evacuation plan "yet", ${ }^{72}$ These statements were made as a 'response' to the 'concerns demonstrated by various Spanish families who, years ago, hosted some of these young Sahrawis when they were children'. ${ }^{73}$ Spanish civil society therefore felt a responsibility not only to trace the situation of Spanish citizens affected by the conflict in Libya, but also that of one particular refugee group with whom they had a long-standing connection. Despite their initial dismissal of an evacuation plan, Polisario ultimately secured the evacuation of these children and adolescents; whether pressure applied by Spanish civil society played a role in securing this outcome, and precisely how Polisario and Algeria negotiated this 'solution', remains to be explored.

Upon the children's departure, UNHCR reported that they had been 'informed' of the evacuation of 753 Sahrawi from Benghazi on an Algerian boat. $^{74}$ This leads us to question why UNHCR was 'informed' rather than more proactively involved in (if not responsible for) their evacuation? Indeed, given that no UNHCR statistical or annual reports have recorded the number of Sahrawi refugee children in Libya (unlike the detailed statistics vis à vis Sahrawis in Cuba), to what extent was UNHCR in fact aware of the presence, whereabouts, total number and protection needs of these refugee children in Libya? Whilst noting that UNHCR's office in

\footnotetext{
70 G Crivello and E Fiddian-Qasmiyeh, 'The Ties that Bind: Sahrawi Children and the Mediation of Aid in Exile' in Chatty and Findlay (eds), above n 11, 83-116.

71 On Spanish civil society's 'responsibility' to protect Sahrawi children and women, see FiddianQasmiyeh, When the Self, above n 11.

${ }_{72}$ Quoted on <http://www.publico.es>, author's translation.

73 ibid.

74 No further details are available to confirm which of the two numbers of Sahrawi evacuees reported by Polisario (916) or to/by UNHCR (753) is correct.
} 
Tripoli had been forced to suspend its operations twice in June 2010, and that its 'engagement on protection issues in the country [was] fragile" ${ }^{75}$ and was 'substantially constrained even before the current crisis ${ }^{96}$ beyond its operational capacity, a broader question is whether UNHCR considers itself to be responsible for the protection of these refugees, as they were in the past in the case of Cuban-based Sahrawi students. ${ }^{77}$

\subsection{Protecting Palestinian Refugees}

Although the presence of Sahrawi refugees in Libya had remained largely unnoticed by the international community (with the exception of Spanish audiences) until their evacuation in April 2011, the UN, United States Department of State (USDOS) and OCHA regularly documented the numbers of Palestinians attempting to cross the Libyan-Egyptian border, those prevented from doing so, and those evacuated to a number of contexts. UNHCR regularly included such details under the 'protection' heading of its reports, denoting its concern for Palestinians displaced by the conflict and, in one instance, included a photograph with the caption: 'UNHCR staff talks to a Palestinian family stranded at the EgyptianLibyan border'. ${ }^{78}$ By 18 May, 'some 655 Palestinians' had been supported by UNHCR, ${ }^{79}$ by 20 May, OCHA had provided 'protection counseling ... to 30 Palestinians aiming to leave Libya', ${ }^{80}$ and, by 3 June, 'UNHCR has also helped 765 Palestinians stranded in a no man's land to travel to Gaza, through the Rafah border crossing, in Egypt'. ${ }^{81}$ Table 3 presents a summary of the figures provided by international organisations vis à

\footnotetext{
75 UNHCR Global Appeal 2011 Update, 89.

76 UNHCR, 'Refugee protection in countries affected by recent events in the Arab World', UNHCR Press Release (23 June 2011).

${ }_{77}$ Although beyond the scope of this article, the author would argue that this case-study parallels a broader disconnect between Sahrawi refugees and the UN agency, as embodied by UNHCR's failure to protect Sahrawi refugee girls reportedly 'abducted' by their birth-families whilst fostered in Spain. Fiddian-Qasmiyeh, When the Self, above n 11. In turn, while Algeria's intervention to evacuate the Sahrawi children and youth from Libya could be interpreted as a 'normal' part of its responsibilities as the Sahrawi's asylum state, it is notable that Algeria has in the past explicitly refused to accept that it is legally responsible for the human rights of Sahrawi refugees, as the Sahrawi's 'host state' and de-jure authority over the camps. Rather, Algeria 'holds that it bears no responsibility with regard to the human rights situation of the Sahrawi people', since it recognises the Sahrawi Arab Democratic Republic's jurisdiction and, in effect sovereignty, over the camps. OHCHR, 'Report of the OHCHR Mission to Western Sahara and the Refugee Camps in Tindouf - 15/23 May and 19 June 2006' (8 Sept 2006) 13; see also Fiddian-Qasmiyeh, 'Transnational Abductions and Transnational Responsibilities? The politics of "protecting”' female Muslim refugees abducted from Spain', Gender, Place and Culture (forthcoming).

78 UNHCR, 'Update no 16: Humanitarian Situation in Libya and the Neighbouring Countries' (4 Apr 2011).

${ }_{79}$ UNHCR, 'Update no 25: Humanitarian Situation in Libya and the Neighbouring Countries' (18 May 2011).

${ }^{80}$ OCHA, 'Libyan Arab Jamahiriya - Crisis, Situation Report No 38' (20 May 2011).

81 UNHCR, 'Update no 27: Humanitarian Situation in Libya and the Neighbouring Countries' (3 June 2011).
} 


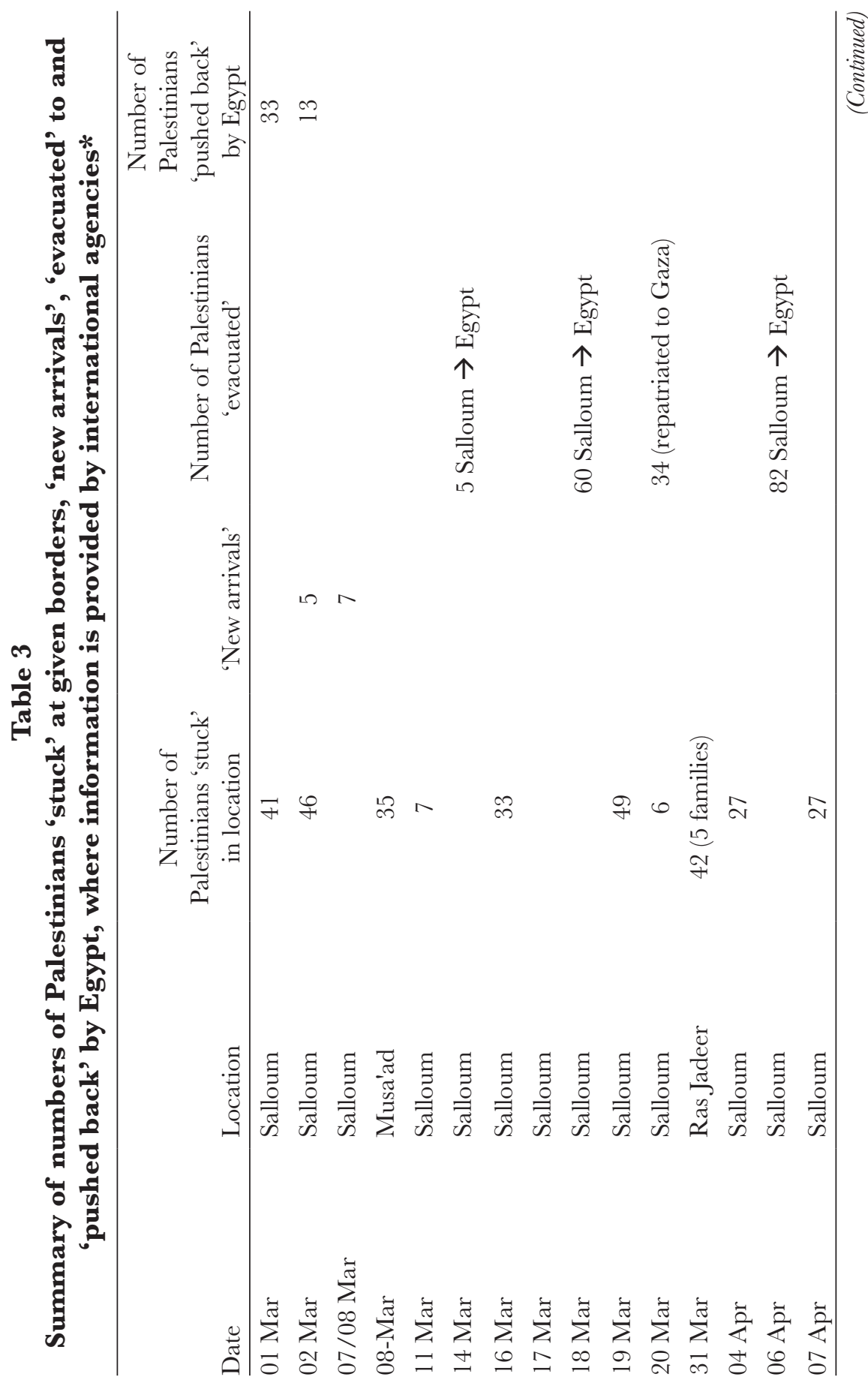




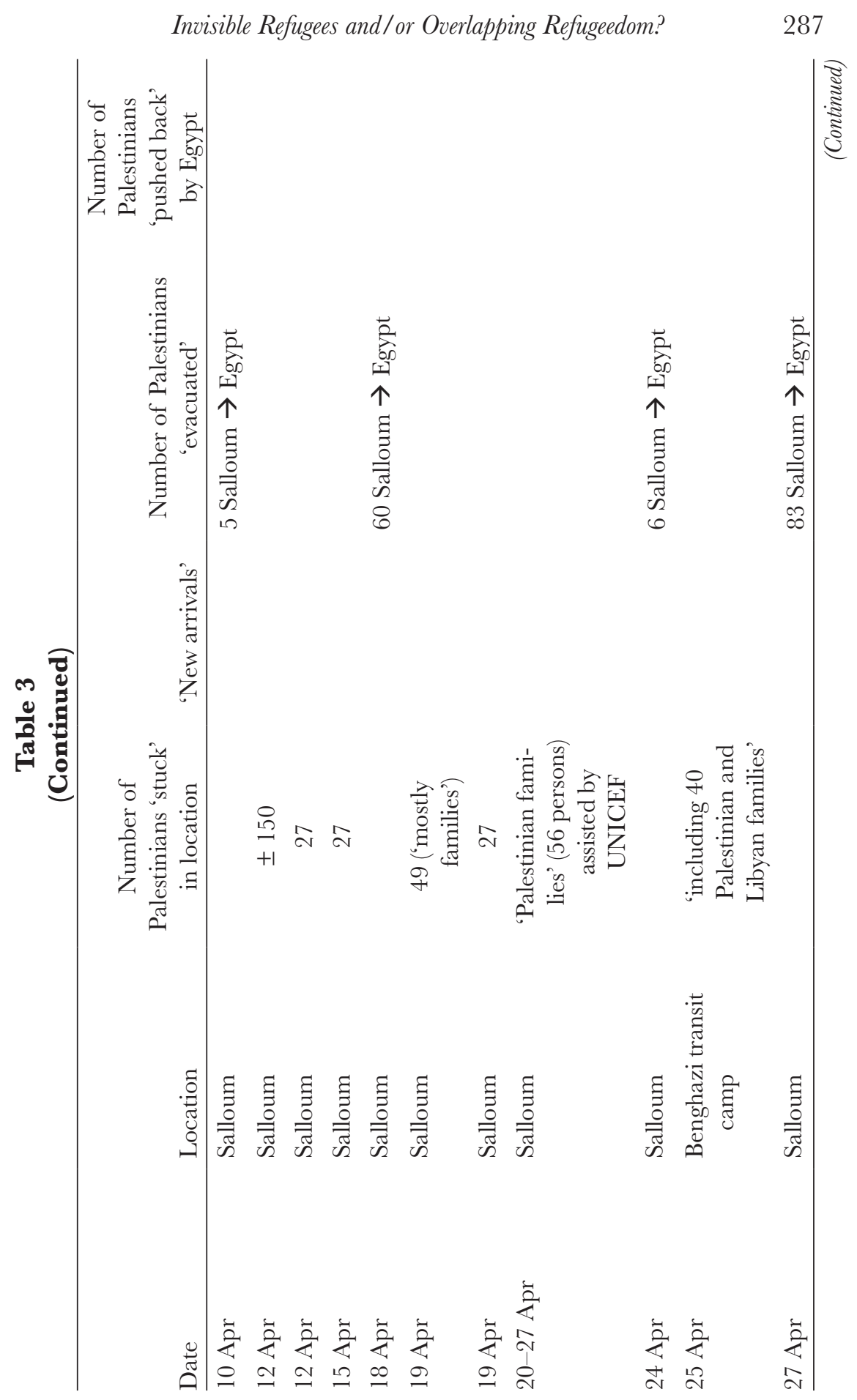




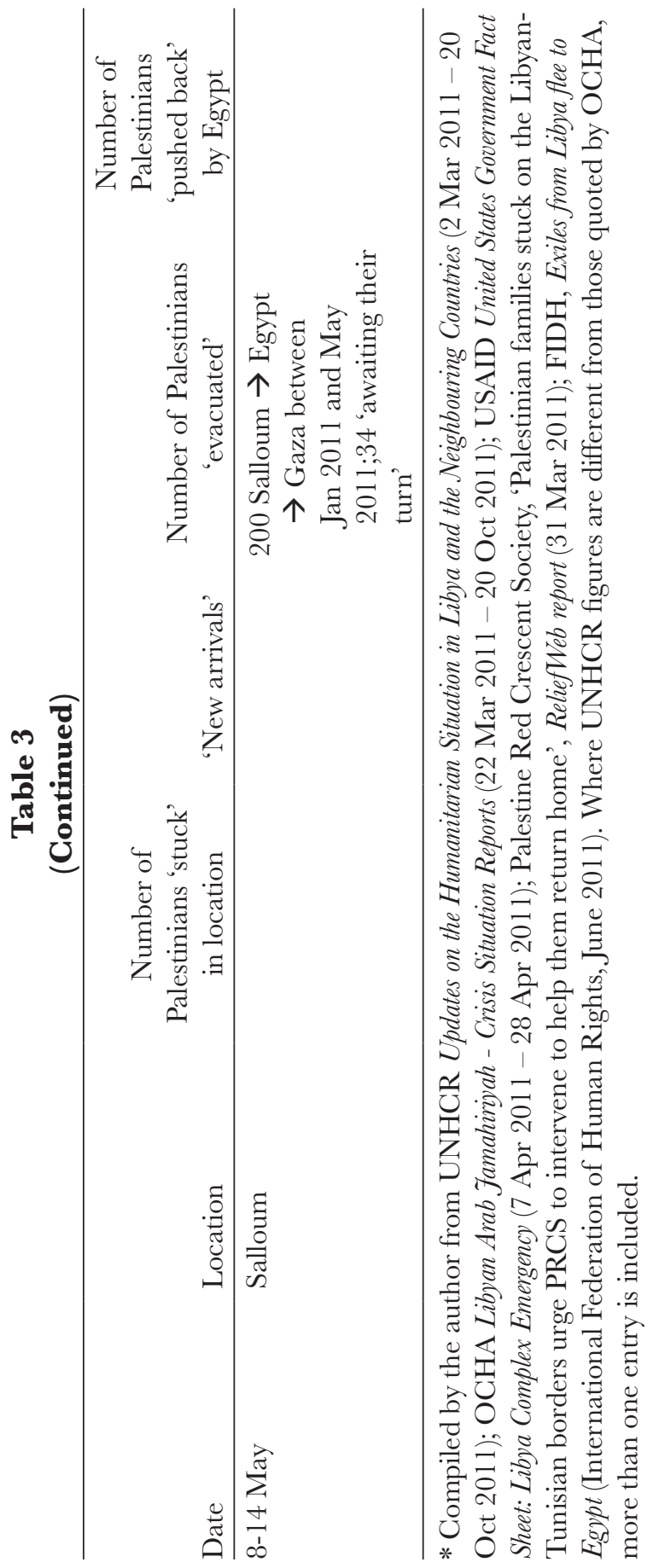


vis Palestinians displaced from/in Libya in their public reports published between 1 March 2011 and 20 October 2011. UNHCR, USAID and OCHA reports and updates were analysed throughout the duration of the conflict, with no references to Palestinians identified in the updates produced from the end of May to the execution of Gaddafi on 20 October 2011.

As in 1995-1996, this table highlights the extent to which the Salloum border has once again witnessed mass population movements, and major restrictions on Palestinians' attempts to cross the Libyan-Egyptian border to seek safety. The figures provided by international agencies are, however, limited, reflecting inconsistencies between agencies (OCHA and UNHCR figures are widely divergent for 12 April and 19 April, for instance), and failing to systematically refer to the demography of the Palestinians affected (such as gender, age and family structure) or, indeed, their legal status. The data presented by these agencies fails to elucidate precisely how many Palestinians have 'successfully' left Libya, and how many, and who (that is, gender, age and point of origin) have remained internally stuck and why. While such an examination is beyond the scope of this article (largely due to an absence of reliable data), in the following section there is a preliminary assessment of the 'solutions' which have been implemented and suggested to date.

First, with reference to the evacuation of Palestinian students from Libya, the Palestinian Ambassador in Tripoli (Atif Mustafa Auda) informed the media that by 6 March 2011 all 104 Palestinian refugeestudents who were attending university and military academies in Libya at the time had been evacuated from the country. ${ }^{82}$ While the Palestinian Ambassador is cited as declaring that the evacuation of the Palestinian students had been ordered by Palestinian President Mahmoud Abbas, ${ }^{83}$ the students themselves have contested this account in the media, claiming that the Palestinian Authority failed to evacuate the students, with Jordan having reportedly offered to transport them alongside their own citizens, even if they did not hold Jordanian Travel Documents. ${ }^{84}$ It must be acknowledged that the Palestinian Authority, like the Polisario Front, has limited resources, as stressed by Nidhal Abu Dukhan (the Palestinian military intelligence director) to Ma'an News Agency, which reports that he, 'added that the Palestinian Authority did not have the capabilities to evacuate its nationals, as other countries have done'. ${ }^{85}$ A comparison of the ways in which Polisario and Algeria on the one hand, and the Palestinian Authorities and Jordan on the other, have addressed the protection needs

\footnotetext{
Ma'an, above n 26.

ibid.

4 ibid, nn 26 \& 28.

55 ibid, above n 28.
} 
of their respective 'refugee populations' would offer a fruitful opportunity to explore the interactions between refugees, their political representatives, and states that may or may not consider themselves to have a responsibility towards these populations.

Secondly, while all Sahrawi refugees were evacuated by one international actor (the Algerian government) to one location (the Algerianbased Sahrawi refugee camps), precisely where Palestinian refugees should, could, or might want to be safely evacuated to, and by whom, is a much more complex issue. This is especially true in the case of those Palestinians who had been registered by UNHCR or who had been offered refugee status or complementary protection in Libya, and also vis à vis the tens of thousands of 'refugee migrant workers' for whom Libya has been their country of habitual residence for up to, and sometimes over, twenty years. It is questionable whether the international community should expect, or can responsibly allow, Palestinians to 'return' to Gaza, the refugee camps in Lebanon, or to the explosive situation in Syria, where Syrian forces attacked a Palestinian refugee camp near Latakia (North-East Syria) on 15 August 2011, displacing over 5,000 Palestinians. ${ }^{86}$ The viability of a refugee camp setting providing effective protection thus emerges in both the Sahrawi and Palestinian contexts; paralleling the critique of references to Sahrawis' 'repatriation' to the Algerian-based camps, the conceptualisation of Palestinians' 'return' to Gaza is undermined by the assertion that most of the forty-eight Palestinians who arrived in Gaza on 23 April were 'Palestinian refugees working in Libya, few have ever visited Gaza, ${ }^{87}$

Proposals for Palestinians to be 'returned' or 'resettled' within the region are highly problematic given historical and contemporary restrictions on

\footnotetext{
86 'Munazamat al-tahrir tudin fi shidda iqtiham mukhayyam al-Raml wa tahj̈r sukanihi' (The PLO strongly denounces the al-Raml camp incursion and the displacement of its people), Dar Al-Hayat (16 Aug 2011); 'Syria assault on Latakia drives 5,000 Palestinians from refugee camp', The Guardian (15 Aug 2011). Addressing the vulnerability of Palestinians in Syria in the summer of 2011, UNRWA's Commissioner General, Filippo Grandi, noted that 'In Yarmouk in June, Hama in July and Latakia in August, the violence extended into the camps with tragic consequences for Palestine refugees': F Grandi, 'Waiting for solutions in uncertain times: Palestine refugees in the Middle East context' (2011), Barbara Harrell-Bond Lecture, Refugee Studies Centre, University of Oxford, 16 Nov 2011. At the time of going to press (5 Mar 2012), violence in Syria has continued to escalate, with increasing reports of Palestinians being detained, abused and killed, including in Yarmouk camp (Damascus) on 29 Feb 2012: 'Syrian regime said to target Palestinians who won't fight uprising', World Tribune (4 Mar 2012). 87 '8th group successfully evacuated from Libya', Ma'an Newes Agency (24 Apr 2011 ) (emphasis added). Further challenges emerge with reference to family unity and family reunification, since the members of a given Palestinian family may hold travel documents or passports from different and distant countries, or no travel document or identity document at all. See Shiblak, above n 35, 44; Palestine Red Crescent Society, 'Palestinian families stuck on the Libyan-Tunisian borders urge PRCS to intervene to help them return home', ReliefWeb report (31 Mar 2011); 'Palestinians in Libya leave for Gaza', Ma'an News Agency (21 Apr 2011); '18 more Palestinians leave Libya', Ma'an News Agency (7 Apr 2011); 'From Libya, Palestinians return home to Gaza', Ma'an News Agency (13 Apr 2011); OCHA, 'Libyan Arab Jamahiriya - Crisis, Situation Report No 35’ (9 May 2011).
} 
Palestinians' movement, and, arguably, the impossibility for Palestinians to effectively locally integrate in host countries in a way that is consistent with international human rights frameworks. Indeed, it is worth recalling that in the context of the 1995-1996 crisis, Gaddafi explicitly justified his actions as follows:

And as I care about the Palestinian cause, and in order to achieve the best interest of Palestinians, I will expel the thirty thousand Palestinians who currently live in my land, and try to secure their return to Gaza and Jericho. If Israel would not let them in, while Egypt does not allow them to pass through its territories, then I shall set a great camp for them on the Egyptian-Libyan borders [that is, Salloum.$^{88}$

In line with Gaddafi's highly paradoxical conceptualisation of 'protection', Palestinians' expulsion from Libya is presented as a means of securing 'their return to Gaza and Jericho', with the name of the 'great camp' established at the Salloum border clearly centralising the Palestinian right of return: Mukhayyam Al-Awda (the Return Camp). In effect, Gaddafi's strategy in 1995-1996 was, ostensibly, to draw attention to Palestinians' inability to return to Gaza and Jericho, utilising the mass concentration of highly visible Palestinians at the border to challenge the political status quo. It could be argued that the 2011 crisis, which was not orchestrated by Gaddafi but which was equally characterised by thousands of Palestinians' inability to cross the Libyan borders to Tunisia or Egypt, even when holding valid travel documents, visibly demonstrates the ongoing vulnerability faced by Palestinians in the region. Their experience of the parallel processes of conflict-induced displacement and conflict-induced immobility, accompanied by an unprecedented degree of violence, can be seen as an instance of history repeating itself, yet again. ${ }^{89}$

\subsection{Alternative solutions: resettlement?}

In light of the major difficulties in securing effective protection for Palestinian refugees within the Middle East and North Africa, illustrated by the historical examples explored above, and currently exacerbated by the ongoing political instability across the region, the possible solution of resettlement outside the region for Palestinians affected by the Libyan conflict appears pivotal. Indeed, long-standing barriers to Palestinian refugees' ability to adequately 'locally integrate' into host countries in the region, and their fluctuating vulnerability, have previously justified the resettlement of Palestinians to third countries outside the region, as evidenced in the precedent of the resettlement of ex-Iraqi Palestinian refugees 'stuck'

88 Quoted by Sirhan in al-Majdal, above n 33, 46 (emphasis added).

${ }^{89}$ Also see A Badwan, 'Al-qalaq al-mutazayid wa haal al-filistiniyin fi libia' (Growing concern for the situation of Palestinians in Libya), Al-Quds (28 Mar 2011). 
at the Iraqi-Syrian and Iraqi-Jordanian borders. ${ }^{90}$ However, in the case of Iraqi Palestinian refugees, between 2006 and 2008 only 381 Palestinian refugees were resettled from the Syrian and Jordanian borders with Iraq, during which period they, and several thousand other Palestinian refugees, were 'stuck' in one of three camps on the border. ${ }^{91}$ Given the delays experienced by Iraqi Palestinians in the recent past, it is essential that such delays are not repeated in the aftermath of the 2011 Uprisings, with the UN reasserting 'the need to identify solutions to resettle some 1,000 third country nationals (mostly Iraqis and Palestinians) at Libya's borders with Egypt and Tunisia who do not wish to return to their countries'. ${ }^{92}$ Despite such statements, however, it is notable that references to resettlement have rarely explicitly referred to Palestinians and typically include figures that underestimate the overall population for whom resettlement emerges as the only viable means of securing an effective durable solution.

It is equally concerning that, on 21 October 2011 , one day after the capture and execution of Colonel Gaddafi in Sirte, the UNHCR announced that new arrivals at the Salloum border would no longer be processed for resettlement, as of Sunday 23 October 2011. It justified this decision as being, 'based on a marked improvement in the situation in eastern Libya, and because UNHCR is refocusing its protection and assistance efforts inside Libya including RSD and resettlement' ${ }^{93}$ It gave reassurance that the more than 1,800 people 'already at Saloum will not be affected and work will continue on finding solutions for them, including resettlement for those found to be refugees' ${ }^{94}$ However, precisely who will be prioritised for resettlement at the border and inside Libya itself, by which states and how soon, remains to be explored, as do the inevitable challenges that will be presented by state and non-state actors who reject even the prospect of resettlement of Palestinians outside the region. A balance must therefore be achieved and maintained between the individual and collective protection needs of Palestinian refugees, and the geopolitical interests of diverse actors, including Middle Eastern and North African states, the Palestinian Authorities, international organisations such as UNHCR and UNRWA, and potential resettlement states themselves. While concerns will inevitably be raised that resettlement outside the region would jeopardise

90 See Goddard, above n 35, 502. In 2003, the UNHCR estimated that the total population of Palestinians in Iraq was 34,000, with 23,000 of these having registered with the UN refugee agency: UNHCR, Briefing Notes, 'Iraq: Mortar attack targets Baghdad Palestinians' (20 Oct 2006).

${ }_{91}$ 'UN closes Palestinian refugee camp straddling Iraqi-Syrian border', UN News Centre (2 Feb 2010); also Jordan, 'U.S. Agrees to Resettle Palestinians Displaced by Iraq War', The Wall Street Fournal (17 July 2009).

92 OCHA, 'Libyan Arab Jamahiriyah - Crisis, Situation Report No 15' (22 Mar 2011) (emphasis added).

93 UNHCR, Briefing Notes, 'Resettlement programme ends at Egypt's Saloum as Libya crisis wanes'

(21 Oct 2011).

94 ibid. 
Palestinians' right of return, it is essential that Palestinians themselves have the opportunity to take decisions vis à vis the best means to secure effective protection for themselves and their families, rather than having decisions and 'solutions' presented by diverse actors on their behalf.

\section{Conclusion}

This article has explored the challenges faced by Sahrawi and Palestinian refugees who were studying and working in Libya at the start of the conflict in February 2011, and the nature and implications of the international community's responses to these challenges. This article has argued that refugees who engage in 'voluntary migration' must not be conceptualised as having lost their claims to the refugee label, suggesting that a new conceptual framework of 'overlapping' and 'multiple' refugeehoods may be appropriate in such circumstances. Having outlined a range of historical and contemporary scenarios of mass expulsion and conflictinduced displacement within and from Libya, in addition to highlighting the 'overlapping invisibility' of Sahrawis and Palestinians as refugees in Libya throughout the 1990s and 2000s, this article has argued that refugees' agency in developing mobile educational and livelihood strategies may be paralleled by fluctuating vulnerabilities arising from local, national or international conflicts. In order to recognise the potential simultaneity of refugees' agency and a range of overlapping vulnerabilities, this article has argued in favour of new hyphenated categories including 'refugee-student' and 'refugee-migrant-worker', whilst also noting the extent to which refugees may become 'internally displaced refugees' unable to leave conflict situations such as Libya.

The particular difficulties and dangers experienced by mobile refugees, including refugee children and youth engaging in educational migration or accompanying their 'refugee-migrant-worker families', raise particularly important questions apropos the viability of mobility itself being proposed by policy-makers as a feasible 'durable solution' for refugees. Indeed, the case-studies examined in this article illustrate the urgency of assessing the protection mechanisms in place to support refugees who 'voluntarily' migrate for economic and educational purposes. Such an assessment must include an evaluation of which state and non-state actors could or should accept the responsibility to protect diverse refugee populations; precisely which 'solutions' can be considered to be appropriate and effective in addressing (rather than reproducing) protection gaps; and how refugees' own preferences can be taken into account throughout decision making processes. 